\title{
Ruimer axiomatisch voorbehoud bij beoordelingsverklaringen!
}

\section{H. Baas}

Ongeacht of de strekking van een reactie positief of negatief is, is het altijd een genoegen om op een artikel commentaar te ontvangen. Daaruit blijkt immers dat het artikel niet alleen is gelezen, maar ook, hetgeen veel meer tot tevredenheid stemt, zelfs intensief is bestudeerd. Dit laatste blijkt overduidelijk uit de reactie van Blokdijk.

Zijn commentaar komt er feitelijk op neer dat: 'het axiomatisch voorbehoud ook bij de beoordelingsopdracht geldt en wel voorzover het bij een controleopdracht ook zou gelden'.

Meer concreet heeft zijn reactie betrekking op het gemaakte onderscheid tussen de volgende twee aspecten van dit voorbehoud bij controle-en beoordelingsopdrachten, namelijk:

a het al dan niet bestaande verschil tussen controleen beoordelingsopdrachten ten aanzien van de (on)mogelijkheden om voortdurend aanwezig te zijn op alle plaatsen waarop zich voor de te controleren dan wel te beoordelen verantwoording relevante gebeurtenissen (kunnen) voltrekken, en; b de al dan niet bestaande verschillen tussen de maatschappelijk aanvaardbare afweging van kosten en nut bij de planning en uitvoering van controle-dan wel beoordelingswerkzaamheden.

Ad a Blokdijk stelt dat het niet gaat om de, overigens door hem betwijfelde, feitelijk mindere aanwezigheid van accountants bij cliënten bij de uitvoering van beoordelingsopdrachten, maar om de onmogelijkheid om voortdurend aanwezig te zijn. Daar die bij beoordelings- en controleopdrachten niet van elkaar verschilt, heeft dit gemaakte onderscheid naar zijn mening geen praktische betekenis.

Discussie over het wel of niet minder aanwezig zijn, heeft weinig zin. Echter aangenomen moet worden dat de uitvoering van beoordelingsopdrachten minder uren vergt dan controleopdrachten. Deze mindere uren zullen ongetwijfeld het gevolg zijn van de mindere aanwezigheid van de accountant bij zijn cliënten. Blokdijk stelt dat dit evenwel geen verband houdt met het beperkte fysieke kunnen van de accountant, maar met het beperkte willen van de opdrachtgever. Hij vervolgt dan met de stelling: 'De beoordelingsopdracht is de wereldwijd gesanctioneerde subjectieve verhindering.'

Met name uit deze laatste constatering van Blokdijk blijkt hetgeen ons verdeeld houdt. In zijn visie moet dus bij een beoordelingsopdracht onderscheid worden gemaakt tussen het niet beperkte fysieke kunnen van de accountant en het wel beperkte willen van de opdrachtgever.

Dit laatste betwijfel ik. De opdrachtgever maakt dit onderscheid niet. Dit onderscheid is namelijk inherent aan de soort opdracht die hij verleent. Een opdrachtgever kan bewust kiezen voor een (goedkopere) beoordelingsopdracht. die naar hem bekend zal zijn, leidt tot een minder betrouwbaar accountantsoordeel en onder meer is gebaseerd op minder werkzaamheden en dientengevolge op een mindere aanwezigheid van de accountant op alle plaatsen waarop zich voor de verantwoording relevante gebeurtenissen (kunnen) voltrekken. Maar dat betekent niet dat deze mindere werkzaamheden en dus mindere aanwezigheid van de accountant het gevolg zijn van enige subjectieve verhindering.

Gegeven de inhoud van de opdracht, in dit geval dus controleren of beoordelen, zal per soort opdracht uitsluitend de accountant de aard en omvang van de te verrichten werkzaamheden bepalen. Inspraak van de opdrachtgever, in de vorm van beperking van de uit te voeren werkzaamheden, is hierbij niet aanvaardbaar. Bij beoordelingsopdrachten dienen derhalve, net als bij controleopdrachten. dergelijke subjectieve verhinderingen onaanvaardbaar te zijn.

De lagere betrouwbaarheid van het oordeel begrepen in de beoordelingsverklaring is dientengevolge mede het gevolg van de mindere aanwezigheid van de accountant. Deze mindere aanwezigheid dient daarom te leiden tot een 'ruimer' axiomatisch voorbehoud.

$A d b$ ledere discussie over de vraag of het onontdekt blijven van een onvolkomenheid in een 
beoordeelde verantwoording te wijten is an de beperktheid van de opdracht of aan het kwantitalief axiomatisch voorbehoud, lijkı, zo stelt Blokdijk, vruchteloos.

Vanzelfsprekend zal de accountant nimmer de aanstichter van een dergelijke discussie zijn. Probleem is evenwel dat de accountant deze 'vruchteloze' discussie niet kan ontgaan. Deze zal immers altijd worden gestart door degene die meent dat onvolkomenheden in de beoordeelde verantwoording ten onrechte niet door de accountiln zijn ontdekt. Om dit met succes te kunnen weerleggen heeft de accountant. aannemende dat hij van mening is dat door hem geen beroepsfout is gemalakt. het axiomatische voorbehoud nodig. Voorwaarde is dan wel dat dit voorbehoud een ruimere strekking heeft dan bij een controleopdracht.

Dit dient overigens automatisch voort te vloeien uit de verschillen tussen een controle- en een beoordelingsopdracht. Indien bij een hoge betrouwbaarheid (=controle) een zekere, doch beperkte (kwantitatieve) omvang van het axiomarische voorbehoud geldt, vanwege de alanvalardbare afweging van kosten en nut. op grond waarvaln de aard en omvang van de uit te voeren werkzaamheden mede worden bepaald, dient bij een lagere $=$ beperktere betrouwbarheid $(=$ beoordeling), op grond van dezellde afweging van kosten en nut een andere $=$ grotere $(\mathrm{k}$ wantitatieve) omvang van het axiomatisch voorbehoud te gelden.

Indien dit niet het geval zou zijn, kan de accountant de uitkomst van de door Blokdijk als vruchteloos aangemerkte. doch door de accountant nict te vermijden discussie, nooil met enige kans op succes voeren.

Tot slot. met Blokdijk ben ik van mening dat er geen cnkel misverstand over kan bestaan dat zowel voor de controleopdracht, als voor de beoordelingsopdracht het primaat van artikel 11 GBR geldt en dat dus de eis van de deugdelijke grondslag gaal boven de eis van de toepassing van de gedetailleerde regelgeving. De enkele verdediging in de vorm van: "ik heb mij volledig aan de Richtlijnen voor de accountantscontrole gehouden. dus valt mij niets te verwijten'. is inderdaad onvoldoende. omdal ook bij volledige naleving van gedetailleerde regelgeving de accountant zich te allen tijde na afloop van zijn controle- dan wel beoordelingswerkzaamheden, de vraag dient te stellen of hij een deugdelijke grondslag voor zijn mededeling heeft verkregen.

Hel axiomatische voorbehoud maakl, zoals bekend. impliciet onderdeel uit van de deugdelijke grondslag. Echter daar de uit te vocren werkzaamheden bij beoordelingsopdrachten een andere alard. omvang en inhoud hebben dan bij controleopdrachten, heeft iedere soort opdracht zijn eigen deugdelijke grondslag en dus ook zijn eigen impliciet daarvan deeluitmakende axiomatische voorbehoud. Dit afwijkende = ruimere voorbehoud maki derhalve impliciet onderdeel uit van de technische specificatie van iedere beoordelingsopdracht.

Dalarom zijn, anders dan achter de titel van de reactic van Blokdijk, achter de titel van dit weerwoord geen vraagtekens, malar uitroeptekens gezet. 